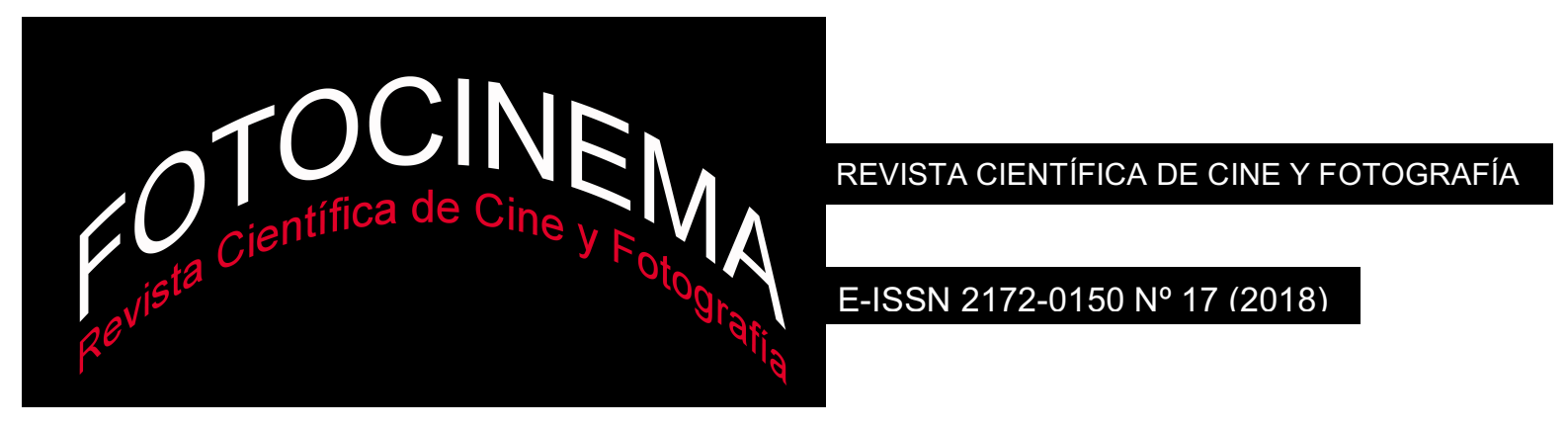

\title{
Las revoluciones en el visor: intervención, persistencia, usos
}

Pascale Thibaudeau (Universidad de Paris 8)

Sonia Kerfa (Universidad de Lyon 2)

Desde los primeros años de su existencia, la fotografía y el cine han estado relacionados con las revoluciones, como podemos comprobar en los clichés de la Comuna de París o en las actualidades fílmicas de la Revolución Rusa. Al mismo tiempo que revolucionaban los modos de representación y nuestra percepción de la realidad, ambos medios supieron como ningún otro representar las revoluciones humanas, captar sus fulguraciones para convertirse en su testigo, cuando no en su estandarte, así como, mediante la ficción, adaptarlas a los gustos y a las ideas del día.

En este número de FOTOCINEMA nos interesamos por las distintas relaciones que se producen entre el acontecimiento revolucionario y las imágenes fílmicas y fotográficas.

¿Qué entendemos por "acontecimiento revolucionario"? ¿Qué tienen en común las revoluciones rusa, mexicana o cubana y "el Mayo del 68", el 15-M o la "Semana Trágica"?, ¿no cabría diferenciar las que produjeron cambios radicales en la organización política, social y económica de las sociedades, de las que fracasaron, algunas aplastadas de manera sangrienta? Convendría seguramente distinguir entre la insurrección, el levantamiento, la rebelión y la revolución propiamente dicha, pero son distinciones que se establecen a partir de los resultados. Cualquier insurrección alberga el germen de una revolución y nadie sabe nunca cuál será el factor desencadenante ni las conjunciones que la favorecerán. Por eso no hemos excluido las "revoluciones vencidas" (Traverso, 2017), ni los movimientos pacíficos portadores de nuevos proyectos radicales de sociedad. Recientemente, la exposición Soulèvements en París ${ }^{1}$, Insurrecciones en Barcelona ${ }^{2}$, concebida por Georges Didi-Huberman, ha reflejado cómo este impulso se manifiesta

\footnotetext{
${ }^{1}$ En el Musée du Jeu de Paume, del 18/10/2016 al 15/01/2017: http://soulevements.jeudepaume.org

${ }^{2}$ En el MNAC, del 24/02/2017 al 21/05/2017: http://www.museunacional.cat/es/insurrecciones 
bajo la forma de "desórdenes sociales, [...] agitación política, [...] insumisión, [...] revueltas y [...] revoluciones de todo tipo"3. Por supuesto, todas las insurrecciones no proceden de un proyecto revolucionario, pero algunos levantamientos poseen esa ambición y la conservan por más que fracasen. De la misma manera, numerosas revueltas aisladas han dado lugar a evoluciones emancipadoras.

\section{La persistencia de las imágenes: entre herencia, conmemoración y banalización}

La coincidencia de la temática de este monográfico con el año de publicación no es fortuita. Cada diez años florecen números especiales de revistas, libros y exposiciones dedicados a los brotes revolucionarios de 1968, y más concretamente al "Mayo francés". Ese momento conmemorativo oscila entre reivindicación, homenaje nostálgico o rechazo contundente, también ofrece la oportunidad de abordar los acontecimientos desde una perspectiva crítica y reevaluarlos a la luz de nuevos planteamientos historiográficos.

En 2018 es aún menos posible escapar del fenómeno puesto que se trata de celebrar el cincuenta aniversario de una revolución que no fue tal, pero que sí trastornó numerosos parámetros sociales y tuvo repercusiones que todavía se hacen sentir. Ahora bien, los "acontecimientos de 1968", eufemismo con el que muy pronto fue designada en Francia, no se limitan al mes de mayo francés, ni siquiera a Europa, como demuestra Mark Kurlansly en 1968: The Year That Rocked The World (2005), bestseller traducido a numerosas lenguas, en el que se interesa por los focos revolucionarios que surgieron en diversos lugares del planeta.

De México a España, donde los estudiantes estuvieron en primera línea, de Checoslovaquia con la Primavera de Praga a Estados Unidos donde se radicalizó el movimiento por los derechos cívicos y la oposición a la guerra en Vietnam, la protesta se extendió a escala mundial, como un fuego propagándose antes de ser sofocado por la geoestrategia de la Guerra Fría. Semejante expansión parece producirse en 2011 con las diferentes insurrecciones en los países árabes (calificadas de Primaveras) o los movimientos de los Indignados del 15-M en España o Occupy Wall Street en Nueva York y otras ciudades de Estados Unidos. Si las luchas anticapitalistas y el altermundialismo no proceden directamente de la estirpe de las internacionales revolucionarias de

3 Dossier de prensa de la exposición. 
principios del siglo XX, comparten con ellas la convicción de que la Revolución no puede ocurrir más que a nivel global, y tienen en común con "Mayo del 68" cierto hedonismo contestatario.

Entre las innumerables publicaciones y manifestaciones que le son dedicados este año en Francia y en el extranjero, señalemos la abundancia de libros sobre la profusa iconografía del 68 (afiches, serigrafías, plantillas...) y más específicamente sobre la fotografía, a la vez huella indiciaria y proveedora de futuros iconos. Es este paso al icono lo que propone considerar la exposición Icônes de Mai $68^{4}$ en la Biblioteca Nacional en París, al centrarse sobre las imágenes que construyeron la memoria colectiva de los acontecimientos, las condiciones de su producción y de su difusión. Audrey Leblanc y Dominique Versavel, sus comisarias, muestran que la cultura visual actual de "Mayo del 68" se fue elaborando en los grandes medios de información a lo largo de los aniversarios, alrededor de una serie de motivos recurrentes y fotografías que se convirtieron en iconos, mientras que otras imágenes permanecían en la sombra. Ponen de manifiesto, por ejemplo, la emergencia y luego la persistencia de una iconografía en blanco y negro, manchada de rojo (consecuencia de los usos que se hicieron de ella después) mientras que la cobertura mediática en la prensa de la época era en su mayoría en color. Subrayan el papel de los "dispositivos culturales, jurídicos, pragmáticos o económicos en la presentación o no de una imagen, en su persistencia o su desaparición, en la posibilidad de hacer de ella un objeto de interrogación y de historia cultural"5 y señalan cómo se impone "un punto de vista exclusivamente estético sobre estas imágenes" y "una recepción más contemplativa que una comprensión o apropiación"6.

La imagen fotográfica, escribía André Bazin, "embalsama el tiempo, lo sustrae [...] a su propia corrupción" (1981, 12). Este embalsamamiento de los acontecimientos por la fotografía, combinado con la hipermediatización, transformó en iconos algunas fotografías. Su poder de penetración, en tiempos en los que la reproductibilidad técnica se ha convertido en diseminación virtual, parece proporcionada a la desaparición de la función política de lo que enseñan. Se puede comprobar en el caso de otros arrebatos revolucionarios o de revoluciones llevadas a cabo; sin embargo, el destino de las imágenes, sean fotográficas o fílmicas, no es la imagen, de ahí la necesidad de situarlas en su contexto, de interrogar las modalidades de su mediatización así como las distintas

4 Del 17 de abril al 26 de agosto de 2018, completada por una exposición virtual en la página web de la Bnf : http://expositions.bnf.fr/mai68/index.htm

5 Audrey Leblanc y Dominique Versavel, "Icônes de Mai 68 : les images ont une histoire ", Bnf, texto en línea, consulta : 2 de julio de 2018, URL : http://expositions.bnf.fr/mai68/arret/o7.htm

${ }^{6}$ Ibídem. Traducido por las autoras. 
etapas que las condujeron hasta nosotros, como nos invitan a hacerlo Audrey Leblanc y Dominique Versavel.

El objetivo de este número es interrogar este destino, siempre incierto. En efecto, el modo en que la fotografía y el cine se apropian de estos acontecimientos y contribuyen a su difusión en el espacio público no es irrelevante. En tanto que artes de la captación y de la manipulación, graban fragmentos de lo real pero también los reconstituyen, los reinventan o los desvían, incluso los instrumentalizan para el imaginario colectivo. Sin librarse nunca por completo de intereses que los sobrepasan o de cuestiones políticas y económicas que los limitan o los mueven.

Así, la mediatización va a privilegiar la exposición, incluso la sobreexposición, de ciertos motivos icónicos -algunos heredados de la pintura romántica-, que dibujan una genealogía del imaginario sobre la revolución, cualquiera que sean el contexto y la época en los que se produce. La calle, las avenidas y las plazas son los espacios de la revolución urbana, y las barricadas, los pavimentos, los puños levantados, el fuego, el humo (el incendio) son las manifestaciones visibles del impulso revolucionario, así como la carrera para huir de las represalias o el brazo alzado para conducir al pueblo sublevado. El eco de La libertad guiando al pueblo de Delacroix convirtió a la "Marianne del 68" de JeanPierre Rey en un nuevo modelo fotográfico, imitado con frecuencia en las fotografías de manifestaciones. La muchedumbre y sus desplazamientos también son motivos recurrentes porque la revolución es la emanación de un cuerpo colectivo (el único verdadero individuo dramático para Eisenstein), es la expresión del pueblo en tanto que entidad una e indivisible. También es persistente la figura de la autoridad represiva que se enfrenta con los revolucionarios: soldados, policías, las fuerzas del orden siempre están presentes, como los estragos causados y las huellas dejadas por los insurrectos. La represión del episodio revolucionario suele ser documentada, sirva para disuadir cuando la revolución ha fracasado o para crear figuras heroicas y mártires cuando ha vencido. En las representaciones de los movimientos contemporáneos aparecen nuevos motivos: el de los hombres y mujeres "sin rostro", disimulados por pañuelos, capuchas o pasamontañas para protegerse de los gases lacrimógenos, no ser identificados por las fuerzas del orden y las cámaras de videovigilancia o, desde una postura igualitaria, para abolir toda forma de jerarquía7.

Paralelamente a la persistencia de ciertas imágenes y a los usos mediáticos que se hacen de ellas, este número se interesa por cineastas y fotógrafos que intervinieron y se

\footnotetext{
7 Véase en este mismo número la entrevista de Philippe Bazin al fotógrafo Bruno Serralongue.
} 
implicaron directamente en los procesos revolucionarios, y se plantearon, algunos desde las premisas de la revolución rusa y los movimientos de vanguardia artística, el problema de la adecuación entre el mensaje revolucionario y su expresión formal. Para muchos de ellos, sólo un lenguaje que se revolucionara a sí mismo sería capaz de participar de la ambición revolucionaria. Eisenstein encarna este ideal, retomado después por numerosos artistas experimentales, el de una revolución de la forma imprescindible a todo verdadero proceso revolucionario. Jean-Luc Godard, a principios de los 70, hará de esta ecuación una aporía cinematográfica.

Los artículos de este número de Fotocinema esbozan una cartografía parcial e incompleta de los movimientos revolucionarios que jalonaron el siglo $\mathrm{XX}$ e iniciaron el actual: España, Argentina, Bolivia, México, Alemania, URSS, Francia, USA, Libia, Mozambique... Desde hace más de un siglo, las imágenes circulan y acercan al mundo, dan cuenta de la permanencia del proyecto revolucionario bajo todas las latitudes. Al mismo tiempo van desdibujando las diferencias sociales, políticas e históricas de sus condiciones de emergencia. Contra la tentación del universalismo romántico y la reducción de cualquier especificidad a un impulso liberador propio de la condición humana, los textos aquí reunidos se interesan por lo que constituye la particularidad de cada uno de estos movimientos y por la complejidad de las relaciones que tejen con ellos las imágenes fílmicas y fotográficas.

\section{Revolución e intervención: ¿una praxis del contrapoder?}

Los modos de intervención, en el espacio público, de masas habitualmente silenciosas y sometidas al poder vigente, caracterizan los brotes revolucionarios como momentos en los que se manifiestan formas diversas de contrapoder. Su registro por las imágenes fílmicas o fotográficas pueden participar de la praxis del mismo, así como su difusión en diferentes medios. Sin embargo, el destino de las imágenes es incierto y su instrumentalización múltiple: entre propaganda y contrapropaganda, las imágenes -a veces las mismas- son armas revolucionarias o contrarrevolucionarias.

La primera parte se abre con un artículo de Jean-Paul Aubert sobre la "Semana Trágica” (Barcelona, 1909), uno de los episodios más violentos que marcaron el inicio de la monarquía de Alfonso XIII. Síntoma de la violencia social y de la injusticia sufrida por la población obrera, la situación insurreccional que estalló en la capital catalana necesitaba una reevaluación de su representación visual. La investigación que lleva a cabo Aubert vuelve sobre el papel de las imágenes y de los titulares de prensa, así como sobre el control, por parte del gobierno, de la narración de los hechos. El uso diferenciado 
que se hizo entonces de la fotografía en el tratamiento del acontecimiento marca una ruptura entre la prensa tradicional y la prensa ilustrada, en pleno auge. Sin embargo, tanto la ausencia como la abundancia de fotografías respondieron a objetivos comunes: quitarles protagonismo político a los insurrectos y poner de manifiesto las huellas de las destrucciones. Este artículo recuerda cómo a la intervención obrera en las calles respondió una doble intervención en las representaciones: la de los órganos de prensa en la articulación de la imagen fotográfica y de la narración del acontecimiento revolucionario, por una parte; la de los propios fotógrafos fascinados por la estética de las ruinas heredada del romanticismo pictórico, por otra.

El cuestionamiento de las formas de representación y la adecuación de éstas con los discursos revolucionarios estuvieron en el centro de los debates que agitaron las izquierdas latinoamericanas en los años 60 y 70, en sintonía con el contexto mundial (luchas anti-imperialistas y anticoloniales, reivindicaciones de minorías indígenas, entre otras cosas). Fue cuando coincidieron además una serie de progresos tecnológicos con nuevas reivindicaciones de cambio social que encontraron en el cine el medio idóneo para dar forma a sus proyectos revolucionarios y fomentar simultáneamente la revolución desde el propio cine.

El caso del director boliviano, Jorge Sanjinés, es paradigmático de la dialéctica entre teoría y praxis según la cual la experimentación revolucionaria ha de compaginarse con la experimentación formal para acabar con el "cine burgués” y dar paso a una nueva cultura de las imágenes que acompañe el surgimiento del "Hombre nuevo". El artículo de Oscar Andrés Pardo Vélez repasa, desde una perspectiva cronológica, las distintas etapas de creación, de duda y también de logros de este cine revolucionario; escribe la historia de una utopía compartida por numerosos directores, examinando algunas películas de Sanjinés a la luz de sus planteamientos teóricos e ideológicos. A diferencia del boliviano, el director argentino Raymundo Gleyser dejó escasos escritos sobre la elaboración de un nuevo lenguaje y se caracteriza por su pragmatismo de cara a la función didáctica del cine, concebido como herramienta de difusión de las ideas revolucionarias y de concienciación de las masas. Como muestra Charo López Marsano, el que participara en los debates internacionales sobre las prácticas cinematografías revolucionarias no impidió que apelara a la ficción clásica para alcanzar un público hermético a las experimentaciones fílmicas. El propio Sanjinés, como bien apunta Pardo Vélez, acabó renunciando a ciertas exigencias formales para que el contenido revolucionario llegara a un público más amplio. He aquí la aporía a la que tienen que enfrentarse los cineastas 
revolucionarios: sea promocionar ideas revolucionarias revolucionando las mismas formas del lenguaje fílmico a riesgo de que sólo una élite intelectual pueda acceder al sentido; sea recurrir a los procedimientos clásicos de manipulación propios del cine dominante para difundir estas ideas, y caer en la propaganda...

Las veleidades fracasadas de Rouch y Godard de entregar las cámaras a los campesinos mozambiqueños para que participaran en la revolución mediante su apropiación de los medios de producción de las imágenes ${ }^{8}$ fueron realizadas, unos decenios más tarde, por las comunidades zapatistas. Estas consideraron, desde el principio, que el proceso de autonomía por el que luchaban no podía desvincularse de una realización audiovisual autóctona y del dominio de los medios de comunicación. Delmar Ulises Méndez Gómez insiste en cómo el Ejército Zapatista de Liberación Nacional (EZLN), desde Chiapas en México, ocupó el espacio mediático y se afirmó en tanto que fuerza pensante, capaz de resistir la propaganda gubernamental narrando su propia versión de la historia. Sin embargo, frente a la abundante producción indígena, elige centrarse en tres documentales realizados a lo largo de más de veinte años, desde una mirada externa a la lucha, pero no exenta de simpatía e implicación. Mediante los tres filmes, recorre la historia reciente e inconclusa de la lucha.

La línea de resistencia a la hegemonía de los discursos no se paró en las zonas indígenas, sino que se reactivó en nuevas formas "plurales”, como apunta Carmen Moreno-Nuño a propósito del movimiento del $15 \mathrm{M}$ en 2011, en Madrid. Allí los protestatarios se autodenominaron "indignados" (Hessel, 2010) y este movimiento, al margen de la ideología marxista tradicional, atrajo por su originalidad y espontaneidad las cámaras de varios directores españoles y de otros países. En la Puerta del Sol también surgieron proyectos de cine desjerarquizado en donde se reprodujera el afán del movimiento de reinventar el espacio público como territorio de debate y de vida. A partir del estudio de cinco documentales producidos entre 2011 y 2012, la autora considera que la variedad de los modos documentales (Nichols, 2013) que presentan, refleja la diversidad y el potencial revolucionario del propio movimiento.

Con este artículo, el primer conjunto de textos se cierra como se había abierto: con una mirada a la España contestataria, cuya persistencia dio lugar durante los primeros meses de la Guerra Civil a una experiencia revolucionaria anarquista única. Una revolución vencida (Traverso, 2017) que, pese a la abundancia de imágenes que la registraron, acabó

\footnotetext{
8 Véase en este mismo número el artículo de José Antonio Jiménez de las Heras y Ricardo Jimeno Aranda.

9 Ver también la experiencia de Bruno Serralongue en la entrevista que le hace Philippe Bazin.
} 
confundiéndose con la propia Guerra Civil. Por su carácter efímero y las circunstancias históricas de su represión, no ha permanecido en la historia internacional de las representaciones fotográficas y fílmicas, como hiciera la revolución por antonomasia: la de 1917.

\section{Creación y Revolución: usos variables}

Pocas veces el arte y las artes visuales en particular han sido vinculados de manera tan radical a una revolución: más que los innumerables discursos y textos teóricos quedan en el imaginario colectivo las huellas de la creación en movimiento, la unión de las vanguardias y de la revolución. El caso paradigmático es el de Serguei Eisenstein con quien se abre la segunda parte sobre las relaciones entre los movimientos revolucionarios, el concepto de revolución y las artes.

Daniel C. Narváez Torregrosa vuelve sobre la figura insoslayable del ruso cuya influencia seminal ya hemos podido comprobar en la voluntad inicial de Jorge Sanjinés y Raymundo Gleyser de lograr una adecuación entre la forma del lenguaje fílmico y el discurso revolucionario. El artículo se centra en la inclusión realizada por Eisenstein, a la vez en su reflexión teórica y en su práctica del cine, de artes exógenas como el kabuki, la pintura y la música de vanguardia. Este recurrir, poco ortodoxo, a formas que acabarían siendo consideradas decadentes y burguesas por los guardianes del estalinismo, configuraba, para el cineasta, las condiciones del surgimiento de un cine revolucionario y total.

La estética rupturista que caracterizó al cine soviético en su fase inicial, acabó remodelada por las exigencias propagandísticas, así como ocurrió con el paso del constructivismo al fotomontaje en los carteles dedicados a las masas analfabetas. El interés de la contribución de Cláudia Raquel Lima estriba en el juego de espejos que establece entre la función subversiva de los fotomontajes de John Heartfield en el contexto del ascenso del nazismo en Alemania, por una parte, y el apoyo al nuevo discurso oficial soviético de los fotomontajes de Klutsis o El Lissitzky, por otra. Si los tres artistas persiguen objetivos distintos, coinciden en que el fotomontaje constituye un agente al servicio de las revoluciones. El cotejo de su trabajo muestra cómo la manipulación de la imagen fotográfica inherente a la práctica del fotomontaje puede servir tanto para contrarrestar otra forma de manipulación (la del discurso embelesador del nazismo), en el caso de Heartfield, como para contribuir a difundir una nueva ideología, en el caso de Klutsis o El Lissitzky. Así podemos plantearnos si los usos políticos del arte del fotomontaje no se derivan de sus propias modalidades de creación. 
La conciencia aguda de Jean-Luc Godard de las limitaciones del lenguaje fílmico (la cámara no es exterior a la realidad filmada) a la que ya hemos aludido, y su trasfondo de escepticismo le llevaron a lanzarse, junto al grupo Dziga Vertov, a la realización de una serie de películas documentales en las que, como demuestra Iván Gómez, se elabora una contranarración de los acontecimientos de mayo del 68 en Francia. Frente a la abundancia de imágenes mediáticas que acaban ocultando la realidad, indagan sobre la imagen ausente de la revolución, sobre su imposibilidad ontológica. Al cuestionar la producción audiovisual y la posibilidad misma del proceso revolucionario, las películas no dejan de tomar una distancia desencantada.

Miguel Irrazu explora por su parte los usos que una serie de prácticas audiovisuales contemporáneas hacen del legado visual del 68 mexicano, desde tres ángulos distintos: el cine militante de intervención política, la tradición del cine experimental y las "prácticas de archivo" como espacios de construcción de una memoria -o post-memoriacolectiva. Examina, a partir del concepto productivo de fantasma y de resto, no sólo las imágenes, los sonidos y las técnicas obsoletas que vuelven y habitan los filmes contemporáneos, sino también los discursos y la radicalidad producida por la modernidad cinematográfica. Interroga en las imágenes fílmicas actuales, el potencial contradictorio de la presencia de los espectros de una revolución nacida muerta.

Si el cine y las imágenes fílmicas, desde sus inicios, han acompañado las revoluciones, en el caso de Mozambique, la revolución, la independencia y el cine nacieron juntos. La revolución que allí condujo a la descolonización se hizo con y dentro del cine, por lo cual este permaneció desde entonces íntimamente determinado por los cambios políticos del país. Dos cineastas en concreto llamaron la atención de José Antonio Jiménez de las Heras y Ricardo Jimeno Aranda en su artículo dedicado a esta cinematografía tan desconocida. El primero, Licinio Azevedo, en tanto que protagonista del proceso revolucionario, la segunda, Margarida Cardoso, como testigo privilegiado del devenir histórico y cinematográfico mozambiqueño; ambos les permiten recorrer la historia de esta joven cinematografía y estudiar la transformación de los usos ideológicos del lenguaje fílmico en su transición del documental a la ficción.

En las antípodas geográficas e ideológicas se encuentra la producción fotográfica de Michael Christopher Brown, fotógrafo estadounidense que se fue a Libia para presenciar la Revolución en 2011. De la experiencia vivida y captada por el visor de su iPhone sacó el libro, Lybian Sugar, estudiado por Jean Kempf en este número. Sitúa las motivaciones que llevaron al fotógrafo a Libia dentro de la tradición y mitología de los fotorreporteros 
de guerra, lo que le lleva a cuestionar su posicionamiento ético y el uso que hace del momento revolucionario. Al buscar una experiencia personal, permanece exterior a lo que presencia y sus imágenes refuerzan la no inteligibilidad de revolución libia.

¿Cómo captar la revolución en el momento en el que se produce? ¿Cómo hacer que estas imágenes sean inteligibles sin orientar su recepción? ¿En qué medida el exceso de imágenes directas no llega a ocultar el acontecimiento? Semejantes preguntas llevaron a Jean-Luc Godard a desconfiar de las imágenes grabadas durante los acontecimientos del 68, considerando que la imagen documental, por su inmersión en la realidad, no documenta ni permite acercarse a la verdad. Entre la postura ética de Godard y el gesto de Brown, se declinan todas las opciones que los autores de este número han recorrido.

\section{Bibliografía}

AAA (1989). Regards sur la Révolution. Cahiers de la Cinémathèque, 53, Perpignan.

Bazin, A. (1981). Ontologie de l'image photographique. Dans Qu'est-ce que le cinéma? París: Gallimard.

Bloncourt, G. (2016). L'œil en colère: photos, journalisme et révolution. Paris, Lemieux éditeur.

Bourdieu, P. (1965). Un art moyen, essai sur les usages sociaux de la photographie. París: Editions de Minuit.

Brunet, F. (2017). La Photographie: histoire et contre-histoire. París : PUF.

Chartreux, F., Larrère, M. et al. (2013). Révolutions: quand les peuples font l'histoire. París: Belin.

Ferro, M. (dir.) (1989). Révoltes, révolutions, cinéma. París: Centre Georges Pompidou, Coll. Cinéma-pluriel.

Hessel, S. (2010). Indignez-vous ! Montpellier: Indigène éditions.

Ihl, O. (2016). La barricade renversée: histoire d'une photographie, Paris 1848. Vulaines-sur-Seine: Éditions du Croquant.

Kurlansly, M. (2005). 1968: The Year That Rocked The World. London: Vintage Book.

Leblanc, A. et Versavel, D. (2018). Icônes de Mai 68: les images ont une histoire. París: Catalogue de l'exposition, Editions de la Bnf.

Lusnich, A. L., Piedras, P., Flores, S. (2014). Cine y revolución en América Latina: una perspectiva comparada de las cinematografías de la région. Imago Mundi, coll. Estudios de nuestra América.

Malia, M. (2008). Histoire des révolutions. París: Tallandier (2006).

Nichols, B. (2013). Introducción al documental. Universidad Nacional Autónoma de México disponible en: www.librosoa.unam.mx/handle/123456789/272

Poivert, M. (2006). L’image au service de la révolution: photographie, surréalisme, politique. París: Le Point du jour éditeur.

Sumpf, A. (2015). Révolutions russes au cinéma. Naissance d'une nation: URSS, 19171985. París: Armand Colin.

Traverso, E. (2017). Imágenes melancólicas. El cine de las revoluciones vencidas. Acta Poética, $\mathrm{n}^{\circ} 38$, Cine y melancolía de izquierda, pp. 13-48, https://revistasfilologicas.unam.mx/acta-poetica/index.php/ap/article/view/778, consulté le 24 août 2017. 